\title{
IN VITRO ANTIMALARIAL POTENCY OF ELEUTHERINE BULBOSA AND ITS EFFECT ON THE MORPHOLOGY OF PLASMODIUM FALCIPARUM
}

\section{LUH SESOTYANING N. ${ }^{1}$, MELVA LOUISA ${ }^{2}$, HENDRI ASTUTY ${ }^{3 *}$, DIN SYAFRUDDIN ${ }^{4}$, PUJI BUDI SETIA ASIH ${ }^{4}$}

${ }^{1}$ Department of Biomedical Science, Faculty of Medicine, Universitas Indonesia, Jakarta, Indonesia. ${ }^{2}$ Department of Pharmacology, Faculty of Medicine, Universitas Indonesia, Jakarta, Indonesia. ${ }^{3}$ Department of Parasitology, Faculty of Medicine, Universitas Indonesia, Jakarta, Indonesia. ${ }^{4}$ Malaria and Vector Resistance Unit, Eijkman Institute for Molecular Biology, Dr. Cipto Mangunkusumo National General Hospital, Jakarta, Indonesia. Email: astutiek@yahoo.com

Received 30 September 2018, Revised and Accepted 27 February 2019

\section{ABSTRACT}

Objective: This study aimed to determine the potential inhibitory effects of Eleutherine bulbosa on the growth of Plasmodium falciparum and its toxic effects on lymphocyte cells.

Methods: We performed a 50\% inhibition concentration ( $\mathrm{IC}_{50}$ ) test of E. bulbosa against P. falciparum, used transmission electron microscopy (TEM) to observe Plasmodium morphology after exposure to E. bulbosa, and determined E. bulbosa's cytotoxic concentration $50 \%\left(C_{50}\right.$ ) against lymphocytes.

Results: The $\mathrm{IC}_{50}$ value of E. bulbosa was $0.62 \mu \mathrm{g} / \mathrm{ml}$. We observed crystals in the mitochondria of parasites under TEM. CC ${ }_{50}$ values at $24 \mathrm{~h}$ and $72 \mathrm{~h}$ were $851.14 \mu \mathrm{g} / \mathrm{ml}$ and $707.94 \mu \mathrm{g} / \mathrm{ml}$, respectively.

Conclusion: The main content of E. bulbosa is naphthoquinones that are suspected of having a mitochondrial target on the malaria parasite. E. bulbosa is not toxic to lymphocytes; therefore, it has a potential as an antimalarial therapeutic.

Keywords: Eleutherine bulbosa, Antimalarial, Toxicity, 50\% Inhibition concentration.

(C) 2019 The Authors. Published by Innovare Academic Sciences Pvt Ltd. This is an open access article under the CC BY license (http://creativecommons. org/licenses/by/4. 0/) DOI: http://dx.doi.org/10.22159/ijap.2019.v11s1.14

\section{INTRODUCTION}

Malaria is a life-threatening disease that has killed many children aged $<5$ years and pregnant women [1]. Globally, the number of malaria cases decreased by $18 \%$ from 262 million cases in 2000 to 214 million cases in 2015 , whereas the mortality rate decreased by $48 \%$ from 839,000 cases in 2000 to 438,000 cases in 2015 [2]. Although malaria prevalence appears to be decreasing, the emergence of parasites that are resistant to antimalarial drugs and vector resistance to insecticides does threaten this trend. Therefore, drug efficacy should be monitored periodically because new therapies should be developed [3].

Currently, the standard method for malaria treatment in Indonesia is artemisinin-based combination therapy [4]. However, the strains of Plasmodium falciparum which are resistant to artemisinin have been detected in five countries in the Mekong region, including Cambodia, Laos, Myanmar, Thailand, and Vietnam [2]. To overcome the problem of resistance to antimalarial drugs, looking at the history of the discovery of quinine from the cinchona tree and artemisinin from Artemisia annua L. (Asteraceae) may lead to the discovery of new antimalarial drugs derived from plants [5].

Research to obtain new antimalarial drugs, either synthetic or sourced from natural ingredients, from plants is currently being performed. A study conducted by Widyawaruyanti and Zaini reported that dichloromethane extract obtained from Artocarpus champeden stem bark could inhibit the growth of $P$. falciparum with an $\mathrm{IC}_{50}$ of $0.99 \mu \mathrm{g} / \mathrm{ml}$. This plant contains compounds such as flavonoids that have antimalarial activity. Flavonoids are suspected to be able to inhibit the growth of $P$. falciparum through the following two main mechanisms: (1) New permeation pathways, by inhibiting the nutrient transport for parasites, and (2) inhibiting hemoglobin degradation and heme detoxification in parasite food vacuoles [6]. In another study that used methanol extract obtained from Averrhoa bilimbi L. leaves, it was reported to be able to inhibit the growth of $P$. falciparum with an $\mathrm{IC}_{50}$ of $2.805 \mu \mathrm{g} / \mathrm{ml}$. A. bilimbi L. leaves contain many luteolin compounds, which are flavonoids. Luteolin shows potential in inhibiting the fatty acid biosynthesis I (FabI) Plasmodium enzyme. The FabI enzyme is a part of fatty acid synthase Type II, also known as enoyl-ACP reductase, and is involved in the final stage of the elongation of the Plasmodium fatty acid chain [7].

Eleutherine bulbosa (Miller) Urban is a plant belonging to the Iridaceae family that originates from South America; this plant is widely grown in Asia and Africa [8]. In Indonesia, this plant is known as dayak onion and is planted in Kalimantan, where the local population uses it as a traditional medicine for the treatment of breast cancer, heart disease, tumors, inflammation, and bleeding and as an immunostimulant [9]. E. bulbosa tubers are known to contain many naphthoquinones and its derivatives such as elecanacine, eleutherol, eleutherine, and eleutherinone. In addition, E. bulbosa tubers contain alkaloids, steroids, glycosides, flavonoids, phenolics, saponins, triterpenoids, tannins, and quinones [10]. Allegedly, the mechanism of the inhibition of $P$. falciparum growth is similar to that of atovaquone, an antimalarial drug containing hydroxynaphthoquinones, because the main content of E. bulbosa comprises compounds belonging to the naphthoquinone group. Hydroxynaphthoquinones act as competitive inhibitors of ubiquinol, especially by inhibiting the electron transport of Plasmodium mitochondria in the bc complex [11]. Studies on E. bulbosa as an antibiotic and anticancer drug have been widely conducted, but those on E. bulbosa as an antimalarial agent are rare. Therefore, we are interested in examining E. bulbosa as an antimalarial agent by testing its antimalarial activity with a $50 \%$ inhibition concentration test $\left(\mathrm{IC}_{50}\right)$, analyzing the inhibition target of $E$. bulbosa through the observation of Plasmodium morphology with transmission electron microscopy (TEM), and testing its toxic effects against lymphocyte cells with a $50 \%$ cytotoxic concentration $\left(\mathrm{CC}_{50}\right)$ test. 


\section{METHODS}

\section{Preparation of sample}

The sample used was E. bulbosa which was obtained from the Department of Pharmacology, Faculty of Medicine, University of Indonesia. Dimethyl sulfoxide was added to the sample, which was then vortexed until completely dissolved.

\section{Preparation of $P$. falciparum parasite culture}

The P. falciparum parasite used was from the 3D7 strain, originated from Tokyo University, Japan (routinely cultured at the Eijkman Molecular Biology Institute). The parasite was cultured in Roswell Park Memorial Institute 1640 medium containing $10 \% \mathrm{AB}$ serum until the percentage of parasitemia reached $2 \%$ with a hematocrit level of $3 \%$. The culture was performed using the Trager and Jensen procedure.

\section{IC $_{50}$ test}

The test was performed using a 96-microwell plate; $180 \mu \mathrm{l}$ of parasite culture was added to each well. The first well containing the control sample was not given any treatment. In the last well, $20 \mu \mathrm{l}$ of the sample was added and gradual dilution performed up to second well. The microwell plate was inserted into a jar candle and kept in an incubator at $37^{\circ} \mathrm{C}$ for $48 \mathrm{~h}$. After incubation, the plate was taken out of the candle jar, the medium was removed, and a thin blood smear was made from the sediment, followed by staining with $10 \%$ Giemsa. The percentage of parasitemia was calculated using a light microscope with $1000 \times$ magnification. To determine the $\mathrm{IC}_{50^{\prime}}$ a graph was created using Microsoft Excel.

\section{Preparation of TEM sample}

TEM samples used parasite cultures with $5 \%$ parasite and $3 \%$ hematocrit level. Overall, $900 \mathrm{ml}$ of the parasite culture was added into each well of the 24-microwell plate. The first well containing the control sample was not treated; to the second well, $20 \mu \mathrm{l}$ of the E. bulbosa sample with $\mathrm{IC}_{50}$ concentration was added. Then, it was incubated in a candle jar at $37^{\circ 0} \mathrm{C}$ for $48 \mathrm{~h}$. After the incubation period, the solution was transferred into a $1.5 \mathrm{ml}$ tube and centrifuged to remove the supernatant. The sediment was washed by adding $500 \mu \mathrm{l}$ of cacodylate buffer and homogenized. It was then left to stand for $15 \mathrm{~min}$ at $4^{\circ} \mathrm{C}$ and shaken using the shaker, followed by centrifugation. The washing process was repeated 3 times, followed by incubation of the homogenate for $48 \mathrm{~h}$ at $4^{\circ} \mathrm{C}$ with shaking.

\section{Preparation of TEM block sample}

At this stage, the sediment was added with $500 \mu \mathrm{l}$ of glutaraldehyde $(2.5 \%)$ and then homogenized and stored for $48 \mathrm{~h}$ at $4^{\circ} \mathrm{C}$ with shaking. It was then centrifuged at $3000 \mathrm{rpm}$ for $5 \mathrm{~min}$, the supernatant was removed, and the sediment was washed with $500 \mu$ l of buffer cacodylate $0.1 \mathrm{M}+3 \%$ sucrose, shaken for $15 \mathrm{~min}$ at $4^{\circ} \mathrm{C}$, centrifuged at $3000 \mathrm{rpm}$ for $5 \mathrm{~min}$, and then washed 3 times. Then, the sediment was supplemented with $500 \mu \mathrm{l} 2 \%$ osmium tetroxide and $2.5 \% \mathrm{~K}_{3} \mathrm{Fe}(\mathrm{CN})_{6}$, incubated for $2 \mathrm{~h}$ at $4^{\circ} \mathrm{C}$ with shaking, and then washed with cacodylate buffer $0.1 \mathrm{M}$ and $3 \%$ sucrose 3 times. Dehydration was performed using gradual concentration ethanol. After the dehydration stage, the sediment was infiltrated by adding $500 \mu \mathrm{l}$ of pure propylene oxide and incubated for $1 \mathrm{~h}$ at room temperature. Furthermore, the processes of embedding, cutting, and coloring were performed to prepare the sample for observation by TEM.

\section{Isolation and preparation of lymphocyte cells}

Blood was added into a tube containing ethylenediaminetetraacetic acid; the lymphocyte cells were isolated using Ficoll gradient reagent. The lymphocyte cell sediment was supplemented with $1 \mathrm{ml}$ of complete medium (Dulbecco's Modified Eagle Medium, 10\% fetal bovine serum, and $1 \%$ Penicillin-Streptomycin) and stained with trypan blue; the lymphocyte cell number was calculated with a hemocytometer. The lymphocyte cell solution was prepared with a density of 100,000 cells $/ 200 \mu \mathrm{l}$.

$\mathrm{CC}_{50}$ test

Five wells (96-microwell plates) were inoculated with $180 \mu \mathrm{l}$ of lymphocyte cell stock solution. The well 1 (control) was left untreated.
To wells 2, 3, 4, and 5, $20 \mu \mathrm{l}$ of E. bulbosa with concentrations of $10^{-2}$, $10^{-4}, 10^{-6}$, and $10^{-8}$ was added, respectively. Homogenization was then carried out. Two plates were made along with a duplicate for each plate. Plate 1 was incubated in an incubator at $37^{\circ} \mathrm{C}, \mathrm{CO}_{2} 5 \%$ for $24 \mathrm{~h}$, whereas plate 2 was incubated for $72 \mathrm{~h}$. After the incubation period, the solution from each well was transferred into $1.5 \mathrm{ml}$ tubes and centrifuged at $1200 \mathrm{rpm}$ for $10 \mathrm{~min}$, the supernatant was removed, $200 \mu \mathrm{l}$ PBS was added, and the sample was homogenized. Next, $10 \mu \mathrm{l}$ of solution was taken and stained with trypan blue; the living and dead cells were enumerated using hemocytometer. The percentage cell viability was calculated using the following formula:

\section{Number of living cells/total number of cells $\times 100 \%$.}

\section{RESULTS}

\section{Analysis of the potential of $E$. bulbosa in the inhibition of P. falciparum growth}

The result of the $\mathrm{IC}_{50}$ test of E. bulbosa on the growth of P. falciparum is presented in Table 1 and Fig. 1.

The $\mathrm{IC}_{50}$ concentration of E. bulbosa was determined to be $0.62 \mu \mathrm{g} / \mathrm{ml}$.

\section{Observation of $P$. falciparum morphology under TEM}

The morphological differences of untreated and treated $P$. falciparum parasites are observed in Figs. 2 and 3.

Analysis of the toxicity effect of $E$. bulbosa on lymphocyte cells In the toxicity test of $E$. bulbosa, lymphocyte cells were used because blood is exposed to chemical compounds/drugs consumed. Therefore, lymphocyte cells are often used by researchers to determine the toxic effects of a new chemical and drug compound [12].

In this test, lymphocyte cells with a density of 100,000 cells per well were incubated with E. bulbosa for 24 and $72 \mathrm{~h}$. These two different incubation conditions were used to determine whether the toxic effects were affected only by the magnitude of the compound concentration or also affected by the duration of exposure to the compound. The concentrations of E. bulbosa used were $336.7 \mu \mathrm{g} / \mathrm{ml}, 3.367 \mu \mathrm{g} / \mathrm{ml}$, $3367 \times 10^{-5} \mu \mathrm{g} / \mathrm{ml}$, and $3367 \times 10^{-7} \mu \mathrm{g} / \mathrm{ml}$. For these concentrations, the cell viability percentages obtained after incubation for $24 \mathrm{~h}$ were $89.78 \%, 97.48 \%, 99.165 \%$, and $100 \%$, respectively. From the results, the $\mathrm{CC}_{50}$ value was not obtained because the highest cell viability percentage obtained was $89.78 \%$. Incubation for $72 \mathrm{~h}$ with the same concentrations of E. bulbosa resulted in the following cell viability percentages of $84.865 \%, 90.64 \%, 92.23 \%$, and $93.75 \%$, respectively. At the highest concentration of $336.7 \mu \mathrm{g} / \mathrm{ml}$, the percentage of cell viability obtained was 84.865 . By comparing the means of the 24-h and 72-h incubation groups by $t$-test using Microsoft Excel, $\mathrm{P}$ value obtained was $0.02(\mathrm{p}<0.05)$; this denoted that there was a significant difference between the two groups. The test was repeated with higher concentrations of $3367 \mu \mathrm{g} / \mathrm{ml}, 2694 \mu \mathrm{g} / \mathrm{ml}, 2020 \mu \mathrm{g} / \mathrm{ml}$, and $1347 \mu \mathrm{g} /$ $\mathrm{ml}$ because $\mathrm{CC}_{50}$ had not been determined. The cell viability percentages after incubation for $24 \mathrm{~h}$ were $21.62 \%, 23.08 \%, 30.56 \%$, and $37.5 \%$ for concentrations $336.7 \mu \mathrm{g} / \mathrm{ml}, 3.367 \mu \mathrm{g} / \mathrm{ml}, 3367 \times 10^{-5} \mu \mathrm{g} / \mathrm{ml}$, and

Table 1: IC $\mathrm{I}_{50}$ of $E$. bulbosa

\begin{tabular}{llll}
\hline Concentration $(\boldsymbol{\mu g} / \mathbf{m l})$ & \multicolumn{1}{l}{ \% Parasitemia } & \% Growth & \% Inhibition \\
\hline 0 & 3.8 & 100.0 & 0.0 \\
$3.367 \times 1^{-5}$ & 2.8 & 74.3 & 25.7 \\
0.0003367 & 2.5 & 65.9 & 34.1 \\
0.003367 & 2.3 & 61.1 & 38.9 \\
0.03367 & 2.1 & 54.9 & 45.1 \\
0.3367 & 2.0 & 52.2 & 47.8 \\
3.367 & 1.7 & 46.0 & 54.0 \\
33.67 & 1.3 & 35.0 & 65.0 \\
336.7 & 0.7 & 18.6 & 81.4 \\
3367 & 0.0 & 0.0 & 100.0 \\
\hline IC $: 50 \%$ inhibition
\end{tabular}

IC : 50\% inhibition concentration, E. bulbosa: Eleutherine bulbosa 


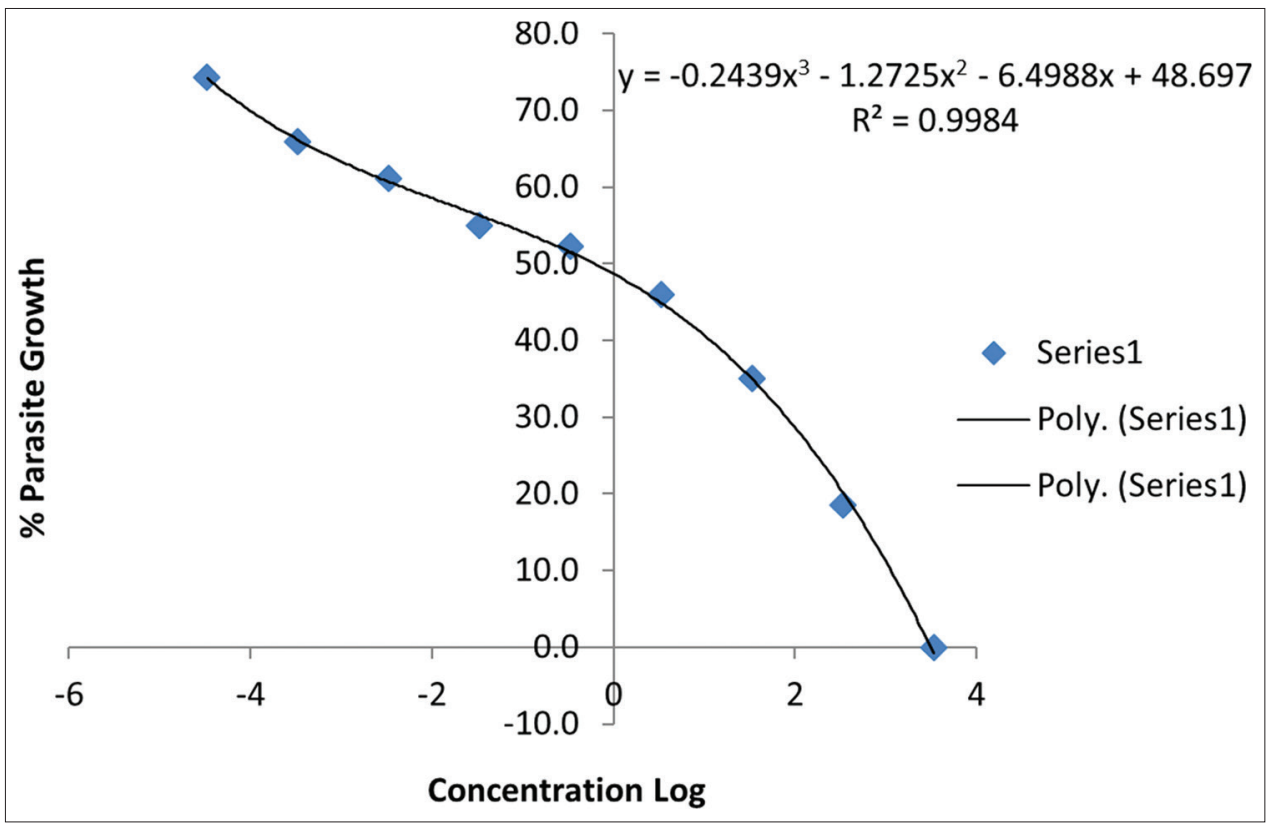

Fig. 1: A 50\% inhibition concentration graph of the effect of Eleutherine bulbosa on Plasmodium falciparum

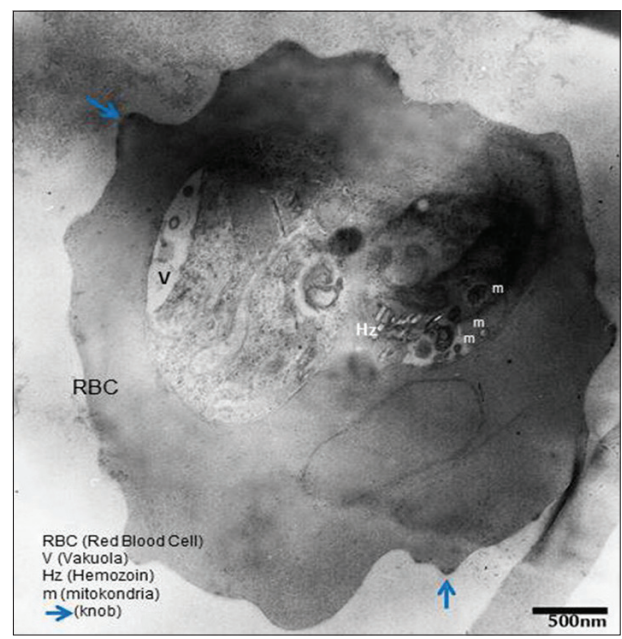

Fig. 2: The morphology of Plasmodium falciparum (control group). The mitochondria of the parasite can be seen with crystals in it (blue arrow)

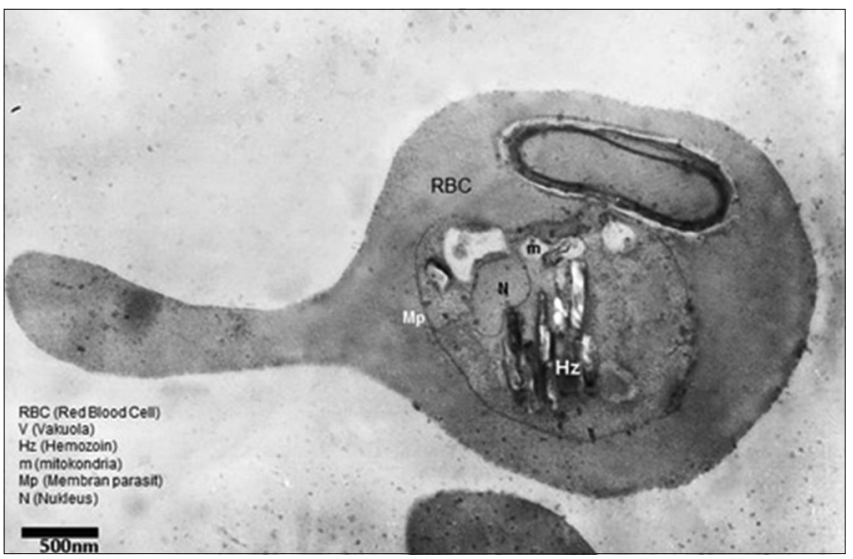

Fig. 3: The morphology of Plasmodium falciparum after exposure to Eleutherine bulbosa at a concentration of $0.62 \mu \mathrm{g} / \mathrm{ml}$ for $48 \mathrm{~h}$. The mitochondria are seen without crystals (m)
Table 2: $\mathrm{CC}_{50}$ of $E$. bulbosa to lymphocyte cells after $24 \mathrm{~h}$

\begin{tabular}{ll}
\hline Concentration $(\boldsymbol{\mu g} / \mathbf{m l})$ & Cell viability $(\%)$ \\
\hline 0 & 100 \\
0.003367 & 100 \\
0.03367 & 99.165 \\
3.367 & 97.48 \\
336.7 & 89.78 \\
\hline$C_{5}: 50 \%$ cytotoxic concentration, E. bulbosa: Eleutherine bulbosa
\end{tabular}

Table 3: $\mathrm{CC}_{50}$ of $E$. bulbosa at higher concentrations to lymphocyte cells after $24 \mathrm{~h}$

\begin{tabular}{ll}
\hline Concentration $(\boldsymbol{\mu g} / \mathbf{m l})$ & Cell viability (\%) \\
\hline 1347 & 37.5 \\
2020 & 30.56 \\
2694 & 23.08 \\
3367 & 21.62 \\
\hline
\end{tabular}

$\mathrm{CC}_{50}: 50 \%$ cytotoxic concentration, E. bulbosa: Eleutherine bulbosa

Table 4: $\mathrm{CC}_{50}$ of $E$. bulbosa to lymphocyte cells after $72 \mathrm{~h}$

\begin{tabular}{ll}
\hline Concentration $(\boldsymbol{\mu g} / \mathbf{m l})$ & Cell viability $(\%)$ \\
\hline 0 & 95.09 \\
0.0003367 & 93.75 \\
0.03367 & 92.23 \\
3.367 & 90.64 \\
336.7 & 84.865 \\
\hline CC $: 50 \%$ Cytotoxic concentration, E. bulbosa: Eleutherine bulbosa
\end{tabular}

$3367 \times 10^{-7} \mu \mathrm{g} / \mathrm{ml}$, respectively. After incubation for $72 \mathrm{~h}$, the percentages of cell viability were $4.62 \%, 17.02 \%, 21.74 \%$, and $23.91 \%$ for the abovementioned concentrations, respectively. The $\mathrm{CC}_{50}$ value after $24 \mathrm{~h}$ was $851.14 \mu \mathrm{g} / \mathrm{ml}$ and after $72 \mathrm{~h}$ was $707.94 \mu \mathrm{g} / \mathrm{ml}$ (Tables $2-5$ and Figs. 4 and 5).

\section{DISCUSSION}

Many studies have used E. bulbosa as an antibiotic and anticancer agent, but research on E. bulbosa as an antimalarial is still very rare. Therefore, this study was conducted to determine the antimalarial potential, 
work mechanism, and toxicity effect of E. bulbosa. To determine the antimalarial potential of this plant, $\mathrm{a} \mathrm{IC}_{50}$ test was conducted. In other studies, experiments have been conducted with methanol extract of srikaya leaves (Annona squamosa) as antimalarial agents, and the $\mathrm{IC}_{50}$ value was found to be $2 \mu \mathrm{g} / \mathrm{ml}$; an $\mathrm{IC}_{50}$ value of $4.9 \mu \mathrm{g} / \mathrm{ml}$ was obtained with the Zanthoxylum zanthoxyloides extract [13] and $22 \mu \mathrm{g} / \mathrm{ml}$ with the root chloroform extract was obtained from Andrographis paniculata. According to Basco et al. and Dolabela et al., criteria of in vitro

Table 5: $\mathrm{CC}_{50}$ of $E$. bulbosa at higher concentrations to lymphocyte cells after $72 \mathrm{~h}$

\begin{tabular}{ll}
\hline Concentration $(\boldsymbol{\mu g} / \mathbf{m l})$ & Cell viability $(\%)$ \\
\hline 1347 & 23.91 \\
2020 & 21.74 \\
2694 & 17.02 \\
3367 & 4.62 \\
\hline
\end{tabular}

$\mathrm{CC}_{50}: 50 \%$ cytotoxic concentration, E. bulbosa: Eleutherine bulbosa antimalarial activity can be divided as follows: $\mathrm{IC}_{50}<10 \mu \mathrm{g} / \mathrm{ml}$ which denotes good activity, $\mathrm{IC}_{50} 10-50 \mu \mathrm{g} / \mathrm{ml}$ which denotes medium activity, IC $_{50} 50-100 \mu \mathrm{g} / \mathrm{ml}$ which denotes low activity, and IC $_{50}>100 \mu \mathrm{g} / \mathrm{ml}$ which denotes no antimalarial activity [7]. According to these criteria, E. bulbosa confers good antimalarial activity. Compared with the $\mathrm{IC}_{50}$ value of the dichloromethane extract obtained from $A$. champeden stem bark $\left(\mathrm{IC}_{50}=0.99 \mu \mathrm{g} / \mathrm{ml}\right.$ ), it is evident that antimalarial activities of E. bulbosa are higher $\left(\mathrm{IC}_{50}=0.62 \mu \mathrm{g} / \mathrm{ml}\right)$.

One way to understand the mechanism of a drug or a compound is to observe the cell morphology of cells affected by the substance using a transmission electron microscope (TEM). TEM has been shown to be useful in the analysis of all cellular components, including the cytoskeleton, membrane system, organelles, cilia, and the special structures involved in cellular development, such as microvilli and synaptonemal complexes [14]. In this study, the morphology of malarial parasites was observed using culture samples of $P$. falciparum that had been exposed to E. bulbosa at a concentration of $\mathrm{IC}_{50}$ that was equal to $0.62 \mu \mathrm{g} / \mathrm{ml}$ and compared with cells that had been exposed

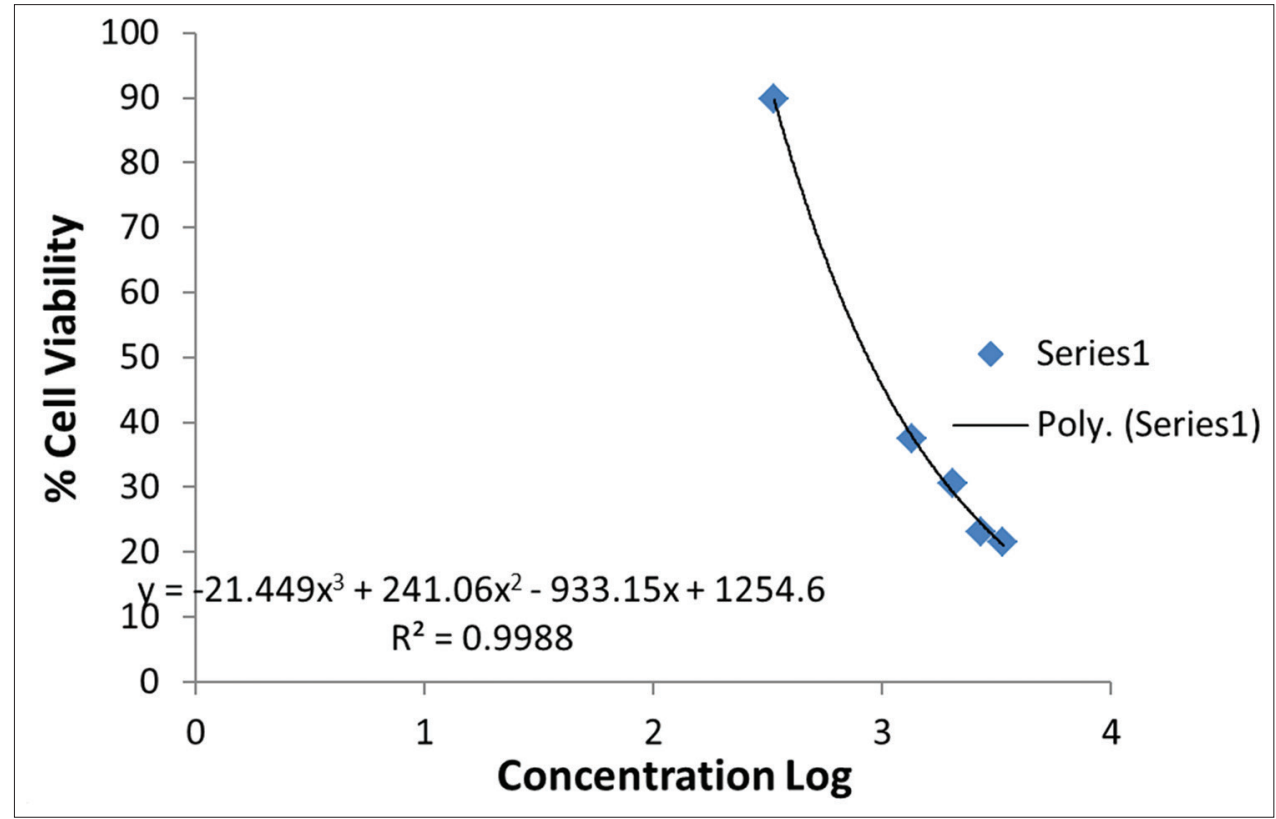

Fig. 4: A 50\% cytotoxic concentration graph of Eleutherine bulbosa to lymphocyte cells after $24 \mathrm{~h}$

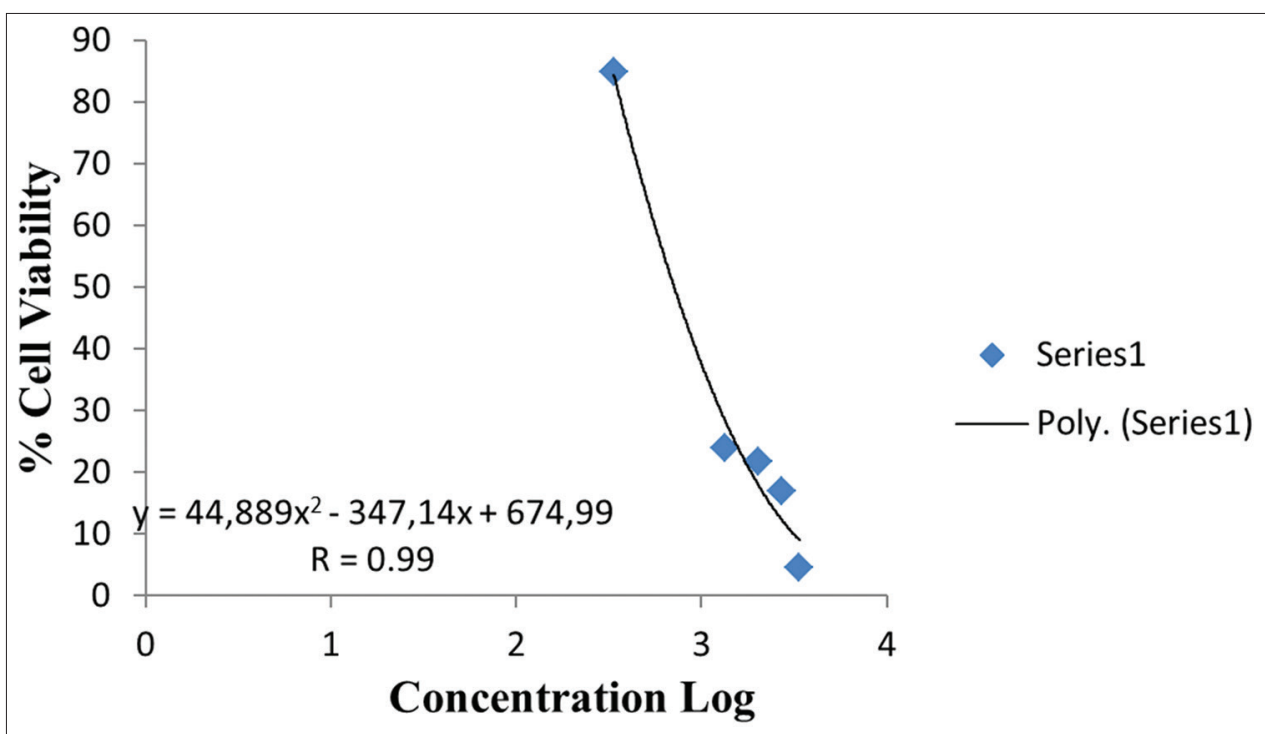

Fig. 5: A 50\% cytotoxic concentration graph of Eleutherine bulbosa to lymphocyte cells after $72 \mathrm{~h}$ 
to a negative control sample. In the control samples, a mitochondrial form of Plasmodium with crystals was observed, whereas, in the treated samples, Plasmodium mitochondria without crystals were observed. This occurred possibly as a result of the inhibition of electron transport to the parasite mitochondria. E. bulbosa contains many naphthoquinone compounds, and these compounds have been shown to have antimalarial activity. A synthetic compound of the naphthoquinone group, hydroxynaphthoquinone, has been shown to have an antimalarial activity with a mechanism of inhibiting the electron transport of Plasmodium mitochondria in complex bc ${ }_{1}$ [11]. From the parasite mitochondrial observations, it was seen that the target of E. bulbosa was on the parasite mitochondria.

\section{CONCLUSION}

E. bulbosa has potential as an antimalarial agent with an $\mathrm{IC}_{50}$ value of $0.62 \mu \mathrm{g} / \mathrm{ml}$ with an inhibition target in the parasite mitochondria. The concentration of E. bulbosa cytotoxic to lymphocyte cells at $24 \mathrm{~h}$ incubation was found to be $851.14 \mu \mathrm{g} / \mathrm{ml}$ and at $72 \mathrm{~h}$ incubation was $707.94 \mu \mathrm{g} / \mathrm{ml}$

\section{CONFLICTS OF INTEREST}

All authors have none to declare.

\section{REFERENCES}

1. Autino B, Corbett Y, Castelli F, Taramelli D. Pathogenesis of malaria in tissues and blood. Mediterr J Hematol Infect Dis 2012;4:e2012061.

2. World Health Organization. WHO Global Malaria Programme. World Malaria Report 2015. Available from: https: //www.apps.who.int/iris/ bitstream/handle/10665/200018/9789241565158 eng.pdf;jsessionid $=5859 \mathrm{DB} 1$ FF50D46B863C585A70A6DCE13? sequence $=1$. [Last accessed on 2016 Jan 28].
3. Indonesian Ministry of Health. Control of Drug and Insecticide Resistance. Malaria Management Guidelines. 2014. p. 129-38.

4. Elyazar IR, Hay SI, Baird JK. Malaria distribution, prevalence, drug resistance and control in Indonesia. Adv Parasitol 2011;74:41-175.

5. Kalauni SK, Awale S, Tezuka Y, Banskota AH, Linn TZ, Asih PB, et al. Antimalarial activity of cassane-and norcassane-type diterpenes from Caesalpinia crista and their structure-activity relationship. Biol Pharm Bull 2006;29:1050-2.

6. Widyawaruyanti A, Zaini NC. Mechanism and antimalarial activities of flavonoids compound isolated from cempedak (Artocarpus champeden). J Bus Psychol 2011;13:67-77.

7. Mulia EP, Tantular IS, Mughni A. In vitro antimalarial activity of belimbing wuluh (Averrhoa bilimbi) Leaves extract on Plasmodium falciparum. Folia Med Indones 2012;48:96-101.

8. Rani VS, Nair BR. Pharmacognostic and physicochemical evaluation of bulbs of Eleutherine bulbosa (Miller) urban, a medicinal plant. J Pharmacogn Phytochem 2015;4:273-7.

9. Kuntorini EM, Nugroho LH. Structural development and bioactive content of red bulb plant (Eleutherine americana); A traditional medicines for local Kalimantan people. Biodiversitas 2010;11:102-6.

10. Amanda FR. Effectiveness of Dayak Onion Extract (Eleutherine Palmifolia L.) Merr in Inhibiting Escherichia coli bacterial growth. Undergraduate Thesis. Jakarta: Universitas Islam Negeri Syarif Hidayatullah; 2014.

11. Nixon GL, Moss DM, Shone AE, Lalloo DG, Fisher N, O'Neil PM, et al. Antimalarial pharmacology and therapeutics of atovaquone. J Antimicrob Chemother 2013;68:977-85.

12. Pourahmad J, Salimi A. Isolated human peripheral blood mononuclear cell (PBMC), a cost effective tool for predicting immunosuppressive effects of drugs and xenobiotics. Iran J Pharm Res 2015;14:979-80.

13. Kovendan K, Murugan K, Panneerselvam C, Aarthi P, Kumar PM, Subramaniam J, et al. Antimalarial activity of Carica papaya (Family: Caricaceae) leaf extract against Plasmodium falciparum. Asian Pacific J Trop Dis 2012;2:S306-11.

14. Winey M, Meehl JB, O’Toole ET, Giddings TH. Conventional transmission electron microscopy. Mol Biol Cell 2014;25:319-22. 